\title{
Identification and probiotic properties of lactobacilli isolated from two different fermented beverages
}

\author{
Iulia-Roxana Angelescu ${ }^{1,2} \cdot{\text { Medana } \text { Zamfir }^{1} \cdot \text { Mihaela-Marilena Stancu }}^{1} \cdot$ Silvia-Simona Grosu-Tudor ${ }^{1}$
}

Received: 30 July 2019 / Accepted: 20 November 2019 / Published online: 7 December 2019

(C) The Author(s) 2019

\begin{abstract}
Purpose Scientific information regarding the microbial content and functional aspects of fermented beverages traditionally produced in certain parts of Europe are scarce. However, such products are believed to have some health benefits and might contain functional bacterial strains, such as probiotics. The aim of the study was to identify such lactic acid bacteria strains isolated from water kefir and, for the first time, from braga, a Romanian fermented beverage made of cereals.

Methods Lactic acid bacteria (LAB) were identified to species level based on (GTG) $)_{5}$-PCR fingerprinting and 16S rRNA gene sequencing. Selected strains were screened for their antibacterial activity and probiotic potential.

Results Eight isolates belonging to seven Lactobacillus species were recovered from the two drinks. The identification of LAB involved in the fermentation of braga (Lactobacillus plantarum, Lactobacillus fermentum, and Lactobacillus delbrueckii) is firstly reported here. Five of the Lactobacillus isolates showed antibacterial activity against pathogenic bacteria, including Listeria monocytogenes, Escherichia coli, Staphylococcus aureus, and Salmonella enterica. Moreover, most of them showed a good resistance to $\mathrm{pH} 2.5$ and some survived at high concentrations of bile salts (up to $2 \%$ ). Two L. plantarum isolates were able to inhibit all the indicator strains, and showed the best viability (about 70\%) after a sequential treatment simulating the passage through the gastrointestinal tract.
\end{abstract}

Conclusion Based on the results, the most promising candidates for designing new probiotic products are: L. plantarum BR9 from braga and L. plantarum CR1 from water kefir.

Keywords Antibacterial activity $\cdot$ Braga $\cdot$ Lactobacillus $\cdot$ Probiotics $\cdot$ Water kefir

Iulia-Roxana Angelescu and Medana Zamfir contributed equally to this work.

Medana Zamfir

medana.zamfir@ibiol.ro

Iulia-Roxana Angelescu

iulia.stefan@ibiol.ro

Mihaela-Marilena Stancu

mihaela.stancu@ibiol.ro

Silvia-Simona Grosu-Tudor

silvia.grosu@ibiol.ro

1 Institute of Biology Bucharest of the Romanian Academy, Splaiul Independentei No. 296, 060031 Bucharest, Romania

2 Faculty of Biotechnology, UASVM-Bucharest, 59 Mărăști Boulevard, 011464 Bucharest, Romania

\section{Introduction}

Foods and beverages obtained through fermentation processes constitute an important part of human diet. Fermentation is used since ancient times for food preservation, but it also contributes to the sensory characteristics and nutritional quality of the final food product. Moreover, the probiotic effect of lactic fermentation products is widely recognized (Sõukand et al. 2015). Results of clinical studies confirm the positive effect of probiotics on gastrointestinal and allergic diseases, and also their contribution to immunomodulation and the benefits of the prophylactic use of probiotics in different types of cancer (Stefanut et al. 2015; Markoviak and Śliżewska 2017; Mitrea et al. 2017). In many regions of the world, fermented foods and beverages based on milk, cereals, or other substrates, are known for their health-promoting properties, although many of them are poorly studied and the health claims are not backed by credible scientific evidence (Marsh et al. 2014). These products have an important role in keeping 
healthy gut microbiota and consecutively, in the prevention of several metabolic and cardio-vascular diseases (Quigley 2013).

Many research studies have focused on the traditional fermented foods and beverages in Africa, South-America, or Asia, but there is little or no scientific information concerning the plant-based fermentations still in use or used until the recent past in certain regions of Europe (Sõukand et al. 2015). A deep microbiological and functional characterization of such "forgotten" foods or beverages could be useful, particularly in terms of interesting tastes and perceived healthiness (Sõukand et al. 2015).

For instance, braga is a refreshing, non-alcoholic drink with oriental specific, prepared from fermented cereals (especially millet, but also wheat bran, corn meal, etc.). In the review on cereal-based fermented foods and beverages (Blandino et al. 2003), braga was included as an indigenous Romanian product, without associated data on the microorganisms involved in its fermentation. Some authors consider braga as a Romanian variety of boza (Afilipoie and Gontariu 2015). Nowadays, it is only produced in few places in the SouthEast of the country, but it used to be a very appreciated drink in the past for its sweet-sour taste and its characteristic odour. It was also believed to have health-promoting effects, probably due to the high content of vitamins, minerals, enzymes, and phytonutrients, similarly with boza (Todorov and Holzapfel 2015).

On the other hand, a more recently described fermented beverage is water kefir or sugary kefir (Gulitz et al. 2011; Fiorda et al. 2017), in which kefir grains are used with a non-dairy substrate (sucrose or brown sugar solution with or without fresh fruit). The historic origin of this beverage is not well known, but a first scientific report dates back in 1889 (Beijerinck 1889). Milk-based kefir has been extensively studied and it is known as an excellent source of probiotics, with many potential health benefits (Prado et al. 2015). However, research on water kefir is still scarce and it mainly deals with its microbial diversity (Laureys and De Vuyst 2014; Fiorda et al. 2017). In general, the microbial species present in water kefir grains include lactic acid bacteria (LAB), mainly lactobacilli and leuconostocs, acetic acid bacteria (Acetobacter species), and yeasts, mainly species of Candida, Saccharomyces, Pichia, Hanseniaspora, and Kluyveromyces (Gulitz et al. 2013; Fiorda et al. 2017). The diversity and quantitative abundance of the different species might differ considerably from region to region (Laureys and De Vuyst 2014; Zanirati et al. 2015). A clear domination of Lactobacillus group is observed within the bacterial composition, similarly with milk kefir. However, several Lactobacillus species (i.e. L. harbinensis, L. hilgardii, L. hordeii, L. nagelli, L. perolens, L. satsumensis), typical for water kefir have been reported (Fiorda et al. 2017).
Moreover, the beneficial effects of sugary kefir beverages on human health have been described in the past years (Rodrigues et al. 2016; Muneer Alsayadi et al. 2018). A large variety of microorganisms with probiotic potential and antibacterial activity against pathogenic microorganisms such as Streptococcus pyogenes, Staphylococcus aureus, E. coli, Listeria monocytogenes, Pseudomonas aeroginosa, etc., have been isolated from sugary kefir grains (Golowczyc et al. 2011).

The aims of the study were to identify the lactic acid bacteria isolated from two types of fermented beverages, namely water kefir and, for the first time, braga and to characterise these strains in terms of antibacterial activity and probiotic potential.

\section{Material and methods}

\section{Isolation and purification of the bacterial isolates}

One sample of commercial braga bought from a cake shop in Bucharest, one sample of home-made water kefir, and one of kefir grains, both obtained from a private person in Bucharest, were available for this study. Customized de Man-RogosaSharpe (MRS) agar media (Man et al. 1960), containing either $20 \mathrm{~g} / \mathrm{l}$ of glucose (MRSg), or $20 \mathrm{~g} / \mathrm{l}$ of fructose (MRSf) as carbon source, were used for isolation of LAB. Appropriate dilutions $\left(10^{-5}-10^{-6}\right)$ of the samples were spread onto the agar media, and then plates were incubated at $37{ }^{\circ} \mathrm{C}$ for $48 \mathrm{~h}$. Colonies were randomly picked up and purified by successive cultivations on liquid and solid medium.

\section{Identification of the isolated strains}

\section{Phenotype characterization}

The pure isolates were tested for their Gram reaction, catalase activity, and morphology. Gram-positive and catalasenegative isolates were stored at $-80^{\circ} \mathrm{C}$ in the corresponding liquid isolation medium, supplemented with $25 \%(\mathrm{v} / \mathrm{v})$ of glycerol. They were further identified to genus and species level by using molecular methods.

\section{(GTG) $)_{5}$-PCR fingerprinting}

Genomic DNA was extracted from overnight cultures, using a Pure Link Genomic DNA kit (Invitrogen, Carlsbad, CA, USA) according to the manufacturer's guidelines. PCR amplifications of genomic DNA were performed with a Mastercycler pro S (Eppendorf, Hamburg, Germany) as described before (Grosu-Tudor et al. 2014), using the (GTG) primer, 5'-GTGGTGGTGGTGGTG-3' (Versalovic et al. 1994). 
Table 1 Taxonomic affiliation of the strains isolated from water kefir and braga using different isolation media

\begin{tabular}{|c|c|c|c|c|c|}
\hline Source & Isolate* & $\begin{array}{l}\text { Isolation } \\
\text { medium }\end{array}$ & Identification & $\begin{array}{l}\text { Closest bacterial type strain name } \\
\text { (accession number) }\end{array}$ & $\begin{array}{l}\text { Percentage of nucleotide } \\
\text { identity }(\%)\end{array}$ \\
\hline \multirow[t]{5}{*}{ Water kefir } & CR1 & MRSg & $\begin{array}{c}\text { Lactobacillus } \\
\text { plantarum }\end{array}$ & & \\
\hline & $\underline{\mathrm{CR} 2}$ & MRSg & Lactobacillus nagelii & & \\
\hline & $\overline{\mathrm{CR} 3}$ & MRSf & $\begin{array}{l}\text { Lactobacillus } \\
\text { satsumensis }\end{array}$ & $\begin{array}{l}\text { Lactobacillus satsumensis NRIC } 0604^{\mathrm{T}} \\
\text { (NR_028658.1) }\end{array}$ & 99.58 \\
\hline & CR4 & MRSf & Lactobacillus nagelii & Lactobacillus nagelii NRIC $0559^{\mathrm{T}}$ (NR_041007.1) & 99.22 \\
\hline & $\underline{\mathrm{CR} 5}$ & MRSf & $\begin{array}{l}\text { Lactobacillus } \\
\text { ghanensis }\end{array}$ & Lactobacillus ghanensis L489 (NR_043896.1) & 99.86 \\
\hline \multirow[t]{3}{*}{$\begin{array}{l}\text { Water kefir } \\
\text { grain }\end{array}$} & CR11 & MRSf & $\begin{array}{l}\text { Lactobacillus } \\
\text { plantarum }\end{array}$ & & \\
\hline & $\underline{\mathrm{CR} 12}$ & MRSf & $\begin{array}{l}\text { Lactobacillus } \\
\text { harbinensis }\end{array}$ & $\begin{array}{l}\text { Lactobacillus harbinensis NBRC } 100982^{\mathrm{T}} \\
\text { (NR_113969.1) }\end{array}$ & 99.86 \\
\hline & CR13 & MRSf & $\begin{array}{l}\text { Lactobacillus } \\
\text { harbinensis }\end{array}$ & & \\
\hline \multirow[t]{7}{*}{ Braga } & BR6 & MRSg & $\begin{array}{l}\text { Lactobacillus } \\
\text { plantarum }\end{array}$ & Lactobacillus plantarum CIP $103151^{\mathrm{T}}$ (NR_104573.1) & 99.22 \\
\hline & BR7 & MRSg & $\begin{array}{l}\text { Lactobacillus } \\
\text { fermentum }\end{array}$ & $\begin{array}{l}\text { Lactobacillus fermentum NBRC } 15885^{\mathrm{T}} \\
\quad(\mathrm{NR} 113335.1)\end{array}$ & 98.00 \\
\hline & BR8 & MRSf & $\begin{array}{r}\text { Lactobacillus } \\
\text { fermentum }\end{array}$ & & \\
\hline & $\underline{\mathrm{BR} 9}$ & MRSf & $\begin{array}{l}\text { Lactobacillus } \\
\text { plantarum }\end{array}$ & & \\
\hline & BR10 & MRSf & $\begin{array}{r}\text { Lactobacillus } \\
\text { delbrueckii }\end{array}$ & $\begin{array}{l}\text { Lactobacillus delbrueckii subsp. lactis DSM } 20072^{\mathrm{T}} \\
\quad \text { (CP022988.1) }\end{array}$ & 91.40 \\
\hline & BR14 & MRSg & $\begin{array}{l}\text { Lactobacillus } \\
\text { fermentum }\end{array}$ & & \\
\hline & BR15 & MRSg & $\begin{array}{l}\text { Lactobacillus } \\
\text { fermentum }\end{array}$ & & \\
\hline
\end{tabular}

*Underlined strains were further screened for antibacterial activity

\section{S rRNA gene sequencing}

16S rRNA gene sequencing was performed for one isolate selected from each cluster of identical genomic fingerprints (seven isolates in total). PCR amplification of 16S rRNA genes and subsequent purification of the amplicons were performed as described previously (Grosu-Tudor et al. 2014). Sequencing of the amplification products was performed at Macrogen Europe (Amsterdam, The Netherlands). The DNA sequencing runs were assembled using the BioEdit software and the sequences were compared with those available in databases of the National Center for Biological Information using the BLAST search program (www.ncbi.nlm.nih.gov/ BLAST/).

\section{Screening for antibacterial activity of the isolated lactobacilli}

Eight strains of lactobacilli (underlined in Table 1), one of each species found in braga and water kefir samples, respectively, were tested for antibacterial activity against the following strains: Bacillus cereus CBAB, Bacillus subtilis B17, Listeria monocytogenes ATCC 1911-1, Staphylococcus aureus ATCC
25923, Salmonella enterica ATCC 14028, and E. coli ATCC25922. Bacterial pathogens were grown in Brain Heart Infusion medium (BHI, Merck, Darmstadt, Germany), at $37^{\circ} \mathrm{C}$, except for the two bacilli, grown at $30^{\circ} \mathrm{C}$. To test the inhibitory activity, $10 \mu \mathrm{l}$ of overnight LAB cultures were spotted on MRSg agar plates and incubated at $37^{\circ} \mathrm{C}$. After the growth of bacteria, MRS agar plates were covered with $\mathrm{BHI}$ agar medium, inoculated with the indicator strains, and incubated overnight at the optimum growth temperature of each indicator strain (as above). Alternatively, cells of the tested LAB strains were heat killed $\left(1 \mathrm{~h}\right.$ at $80^{\circ} \mathrm{C}$ ) before being spotted and tested for antibacterial activity.

In order to determine the nature of the inhibition, several approaches were used. Firstly, LAB cultures were centrifuged for $10 \mathrm{~min}$ at $\times 10,000 \mathrm{~g}$. Cells were washed, suspended in $0.8 \%$ saline, and spotted $(10 \mu \mathrm{l})$ on BHI plates previously inoculated with the indicator strains. Secondly, cell free culture supernatants (CFCS) were tested for antibacterial activity using the agar well method (Mayr-Harting et al. 1972). Finally, CFCS were subjected to ammonium sulphate precipitation (60\% saturation). The precipitates thus obtained were dissolved in potassium phosphate buffer $(5 \mathrm{mM}, \mathrm{pH} 6.5)$ and their activity was tested against the indicator strains. 


\section{Production of lactic acid}

Lactic acid production was determined using HPLC, in order to check if this correlates with the antibacterial activity of the producing strain. A Jasco HPLC System (Jasco Europe, Cremella, Italy), equipped with a PRPx300 (Hamilton, Switzerland) column, maintained at $60^{\circ} \mathrm{C}$, and coupled with a photodiode array (PDA) detector, was used. Elution was performed with $2.5 \mathrm{mM} \mathrm{H}_{2} \mathrm{SO}_{4}$, at a flow rate of $0.5 \mathrm{ml} /$ $\mathrm{min}$. All determination were done in triplicate and the results are given as mean value \pm standard deviation (SD).

\section{Probiotic potential}

\section{PCR amplification for the detection of stress-related genes}

DNA extracted from the tested strains was screened through PCR amplification for the presence of several genes involved in bile salt tolerance (LBA 1446, bsh), survival at low $\mathrm{pH}$ (LBA 1272, groEL), or tolerance to both low $\mathrm{pH}$ and bile salts $(\operatorname{clpL})$ (Turpin et al. 2011). The PCR mixture $(25 \mu \mathrm{l})$ contained $0.5 \mu \mathrm{l}$ dNTP mix (Promega), $1.25 \mu \mathrm{l}$ of each primer, $2.5 \mu \mathrm{MgCl}_{2}, 0.125 \mu \mathrm{l} \mathrm{Taq}$ DNA polymerase (Promega), $5 \mu \mathrm{l}$ Taq buffer, and $3 \mu \mathrm{l}$ of the DNA template. The PCR conditions were as follows: initial denaturation for $5 \mathrm{~min}$ at $94^{\circ} \mathrm{C}$, 35 cycles of $94^{\circ} \mathrm{C}$ for $30 \mathrm{~s}$, an annealing temperature depending on the primer for $1 \mathrm{~min}$, and $72{ }^{\circ} \mathrm{C}$ for $1 \mathrm{~min}$, and a final elongation at $72{ }^{\circ} \mathrm{C}$ for $10 \mathrm{~min}$. The PCR products were then separated on an agarose gel (1.5\%), to check the presence of the specific amplicons (Table 2).

\section{In vitro determination of acid, enzymes, and bile tolerance}

Tolerance to low $\mathrm{pH}$, enzymes, and bile salts was determined in vitro for the strains showing a high antibacterial activity against several indicator strains. Tested strains were cultivated overnight in MRSg, at $37^{\circ} \mathrm{C}$. Bacterial cells were collected by centrifugation $(10 \mathrm{~min}$ at $\times 5000 \mathrm{~g})$ and resuspended in: MRSg (control), MRSg with $\mathrm{pH}$ adjusted to 2.5 (with $1 \mathrm{~N}$ $\mathrm{HCl}$ ), MRSg supplemented with various concentrations
$(0.2 \%, 0.4 \%, 0.8 \%$, and $2 \%)$ of bile salts (Fluka, Germany), MRSg (pH adjusted to 2.5 ), supplemented with $0.3 \%$ pepsin (Sigma-Aldrich, Germany), and MRSg (pH adjusted to 7.0) supplemented with $0.1 \%$ pancreatin (Serva Electrophoresis $\mathrm{GmbH}$, Germany), respectively. Bacterial cells were incubated for $3 \mathrm{~h}$ at $37^{\circ} \mathrm{C}$ in these environments and then, the viable cells were counted by plating on MRSg agar. The results are expressed as the percentage of living cells after $3 \mathrm{~h}$ of incubation reported to the viable cells number of the control.

\section{Survival of tested strains under conditions simulating the passage through the gastrointestinal tract}

The five strains showing good antibacterial activity were cultivated overnight in MRSg, at $37^{\circ} \mathrm{C}$. The CFU counts were determined for each culture, and were used as controls. Cells were then collected by centrifugation $(10 \mathrm{~min}$ at $\times 5000 \mathrm{~g})$, resuspended in MRSg with $\mathrm{pH}$ adjusted to 2.5, and incubated for $1 \mathrm{~h}$ at $37^{\circ} \mathrm{C}$. Cells were further collected by centrifugation, resuspended in MRSg, $\mathrm{pH} 2.5$, supplemented with $0.3 \%$ pepsin, and incubated again for $30 \mathrm{~min}$ at $37^{\circ} \mathrm{C}$. Finally, cells were collected and resuspended in MRSg with $\mathrm{pH}$ adjusted to 7.0 , supplemented with $0.1 \%$ pancreatin and $2 \%$ bile salts, except for strain $L b$. ghanensis CR5, for which we used $0.2 \%$ bile salts, final concentration. Suspensions were incubated for $3 \mathrm{~h}$ at $37^{\circ} \mathrm{C}$. After each step of the treatment, the CFU counts were determined and the viability was expressed as the percentage of living cells reported to the viable cells number of the control.

\section{Results}

\section{Isolation and identification of the LAB strains}

Seven Gram-positive isolates were obtained from the sample of braga and ten from the water kefir sample. Two of the latter isolates were catalase-positive and were no longer studied. Based on the $(\mathrm{GTG})_{5}$-PCR profile similarity, the 15 remaining isolates were grouped in seven clusters (results not shown).

Table 2 List of primers used for the detection of stress-related genes (Turpin et al. 2011)

\begin{tabular}{|c|c|c|c|}
\hline Gene & Primer sequence & Annealing temperature $\left({ }^{\circ} \mathrm{C}\right)$ & Expected amplicon size (bp) \\
\hline \multirow[t]{2}{*}{ groEL } & F: TTCCATGGCKTCAGCRATCA & \multirow[t]{2}{*}{58} & \multirow[t]{2}{*}{168} \\
\hline & R: GCTAAYCCWGTTGGCATTCG & & \\
\hline \multirow[t]{2}{*}{ LBA 1272} & F: GGCCGGTGTTCCACTAGTCC & \multirow[t]{2}{*}{58} & \multirow[t]{2}{*}{210} \\
\hline & R: ACGTTGGGTCGATTTGACGA & & \\
\hline \multirow[t]{2}{*}{$\operatorname{clp} L$} & F: GCTGCCTTYAAAACATCATCTGG & \multirow[t]{2}{*}{56} & \multirow[t]{2}{*}{158} \\
\hline & R: AATACAATTTTGAARAACGCAGCT T & & \\
\hline \multirow[t]{2}{*}{$b s h$} & F: ATTCCWTGGWTWYTGGGCA & \multirow[t]{2}{*}{58} & \multirow[t]{2}{*}{384} \\
\hline & R: AAAAGCRGCTCTNACAAAWCKAGA & & \\
\hline LBA 1446 & F: GCTGGAGCCACACCGATAACR: & 58 & 275 \\
\hline
\end{tabular}


The DNA extracted from a representative isolate of each cluster was submitted to $16 \mathrm{~S}$ rRNA gene sequencing. Results are included in Table 1, which shows the taxonomic affiliation of the 15 isolates, together with the corresponding isolation medium. The percentage of nucleotide identity of the sequenced DNA with the sequence of a type strain is also shown.

The isolates from braga were mainly identified as L. fermentum (four isolates) and L. plantarum (two isolates). The isolates were recovered from both MRSg and MRSf medium (Table 1). One isolate recovered from MRSf was identified as L. delbrueckii. Among the five isolates obtained from the water kefir sample, one was identified as L. plantarum, isolated from MRSg, and two as Lactobacillus nagelli, isolated from both growth media. Moreover, one isolate of Lactobacillus satsumensis, and one of Lactobacillus ghanensis were only recovered from MRSf. From the kefir grain, we could only get one L. plantarum and two Lactobacillus harbinensis isolates; they were only recovered from MRSf medium (Table 1).

However, all the strains isolated from MRSf were also able to grow on MRSg, and therefore, MRSg was further used for the growth of all isolates.

\section{Antibacterial activity of the isolated lactobacilli}

Except for L. nagelii CR2, which had a slight and variable inhibitory activity against the two bacilli, all the other tested LAB strains exhibited a clear antagonistic activity against at least two of the indicators used in this study. The antibacterial activity was variable among the strains (Table 3 ). L. fermentum BR8 and L. delbrueckii BR10 were only able to inhibit B. cereus and B. subtilis, with BR8 being more effective. The other lactobacilli had the ability to inhibit, to a certain extent, all the indicator strains. The highest inhibition was observed against the two bacilli. L. plantarum BR9 had a high inhibitory activity against $L$. monocytogenes and $E$. coli. L. plantarum CR1 and L. satsumensis CR3 were very effective against $S$. enterica and $E$. coli, while L. ghanensis CR5 against $S$. aureus. Finally, L. harbinensis CR12 showed a high inhibitory activity against most of the indicator strains (Table 3).

However, no inhibitory activity was detected when cells were heat killed or when the living cells were washed and suspended in saline before being tested (results not shown). Moreover, neither CFCS nor the ammonium sulphate precipitated CFCS inhibited any of the indicator strain (results not shown).

\section{Production of lactic acid}

Most of the strains produced over $140 \mathrm{mM}$ lactic acid (Table 3), with the highest production for L. ghanensis CR5 (about $170 \mathrm{mM}$ ). Only two strains produced less lactic acid, namely L. fermentum BR8 (about $97 \mathrm{mM}$ ) and L. harbinensis CR12 (about $130 \mathrm{mM}$ ).

\section{Probiotic potential}

\section{PCR amplification for the detection of stress-related genes}

Among the genes screened for the survival at low $\mathrm{pH}, \mathrm{clpL}$ and LBA 1272 were detected in all eight tested strains, although the bands corresponding to the specific amplicons had variable intensity (Fig. 1). The gene groEL was found in five of the eight strains, except for L. nagelli CR2, L. satsumensis CR3, and L. ghanensis CR5. Resistance to bile salts was screened using the primers for $b s h, c l p L$, and LBA 1446 genes. LBA 1446 genes were detected in almost all strains, except for L. ghanensis CR5, while bsh genes were only found in the two L. plantarum strains, BR9 and CR1. These two strains were the only ones harbouring all the screened genes.

\section{In vitro determination of acid, enzymes, and bile tolerance}

Except L. harbinensis CR12, all strains showed a very good survival at $\mathrm{pH} 2.5$ (Table 4). The percentage of viable cells was above $90 \%$ for most of these strains, while for CR12, it was about $39 \%$. The two L. plantarum strains, and also L. satsumensis CR3 showed a very good resistance to high concentrations of bile salts (up to $2 \%$ ), with a percentage of viable cells of about $50 \%$ or above. A lower viability was detected for L. harbinensis CR12 (about 49\%, and 45\%, in the presence of $0.8 \%$ and $2 \%$ bile salts, respectively). L. ghanensis CR5 did not survive at such high levels of bile salts. However, a high percentage of viable cells (about $78 \%$ ) was recorded in the presence of $0.2 \%$ bile salts, while at $0.4 \%$ bile salts, the percentage was much lower (about 39\%).

The tested strains were not significantly affected by the pancreatin, the viability of most of them being above $90 \%$ (Table 4). The two L. plantarum strains kept a high viability (over 90\%) after the treatment with pepsin. The other strains were affected in a variable degree, but the viability loss can also be attributed to the low $\mathrm{pH}(\mathrm{pH} 2.5)$ of the medium used for this treatment.

\section{Survival of tested strains under conditions simulating the passage through the gastrointestinal tract}

L. plantarum BR9 and L. plantarum CR1 showed a good survival rate (over $70 \%$ ) after the treatment simulating the passage through the gastrointestinal tract (GIT) (Table 5). L. satsumensis CR3 and L. harbinensis CR12 completely lost their viability after the sequential analysis, although the individual treatments with pepsin, pancreatin, and bile salts did not have such a dramatic effect, the viability rate being at least 
Table 3 Lactic acid production (HPLC) and antibacterial activities (spots overlayed with indicator strains) of L. fermentum BR8, L. plantarum BR9, and CR1, L. delbrueckii BR10, L. nagelli CR2, L. satsumensis CR3, L. ghanensis CR5, and L. harbinensis CR12

\begin{tabular}{|c|c|c|c|c|c|c|c|}
\hline \multirow{2}{*}{$\begin{array}{l}\text { LAB } \\
\text { strain }\end{array}$} & \multirow{2}{*}{$\begin{array}{l}\text { Lactic } \\
\operatorname{acid}^{\mathrm{a}} \\
(\mathrm{mM})\end{array}$} & \multicolumn{6}{|l|}{ Indicator strain } \\
\hline & & $\begin{array}{l}\text { Bacillus cereus } \\
\text { CBAB }\end{array}$ & $\begin{array}{l}\text { Bacillus } \\
\text { subtilis } \mathrm{B} 17\end{array}$ & $\begin{array}{l}\text { Listeria monocytogenes } \\
\text { ATCC 1911-1 }\end{array}$ & $\begin{array}{l}\text { Staphylococcus aureus } \\
\text { ATCC } 25923\end{array}$ & $\begin{array}{l}\text { Salmonella enterica } \\
\text { ATCC } 14028\end{array}$ & $\begin{array}{l}\text { E. coli ATCC } \\
25922\end{array}$ \\
\hline BR8 & $97 \pm 1$ & +++ & +++ & - & - & - & - \\
\hline BR9 & $140 \pm 4$ & +++ & +++ & ++ & + & + & +++ \\
\hline BR10 & $153 \pm 2$ & + & ++ & - & - & - & - \\
\hline CR1 & $142 \pm 3$ & ++ & +++ & + & + & ++ & +++ \\
\hline CR2 & $158 \pm 1$ & $+/-$ & $+/-$ & - & - & - & - \\
\hline CR3 & $147 \pm 3$ & +++ & +++ & + & + & ++ & ++ \\
\hline CR5 & $170 \pm 5$ & $+/-$ & +++ & + & +++ & + & + \\
\hline CR12 & $130 \pm 2$ & +++ & +++ & ++ & +++ & + & +++ \\
\hline
\end{tabular}

${ }^{\mathrm{a}}$ results are given as mean value \pm standard deviation

- no inhibition zone; + diameter of the inhibition zone $\geq 18 \mathrm{~mm} ;++$ diameter of the inhibition zone $\geq 25 \mathrm{~mm} ;+++$ diameter of the inhibition zone $\geq$ $30 \mathrm{~mm} ;+$ /- variable

50\%. Finally, L. ghanensis CR5 kept a good viability (over $50 \%$ ) after the sequential analysis, but only when we used $0.2 \%$ bile salts. Higher concentrations of bile salts resulted in the complete loss of the viability.

\section{Discussion}

The microbial content of Romanian braga was not reported yet, but taking into account its similarity with boza, in terms of preparation and taste, it is expected to find similar microorganisms in both drinks (i.e. lactobacilli, leuconostocs, and yeasts) (Blandino et al. 2003; Mollendorff et al. 2016).

The LAB diversity of our sample of braga was limited to three Lactobacillus species, namely L. plantarum, L. fermentum, and L. delbrueckii, possibly due to the storage/ preservation methods. While the first two Lactobacillus species are widely spread among fermented foods, including fermented plant foods, L. delbrueckii was mostly isolated from milk-based fermented foods. However, some subspecies of $L$. delbrueckii, namely delbrueckii, and the more recently described sunkii, and jakobseni, have been found in cereal and
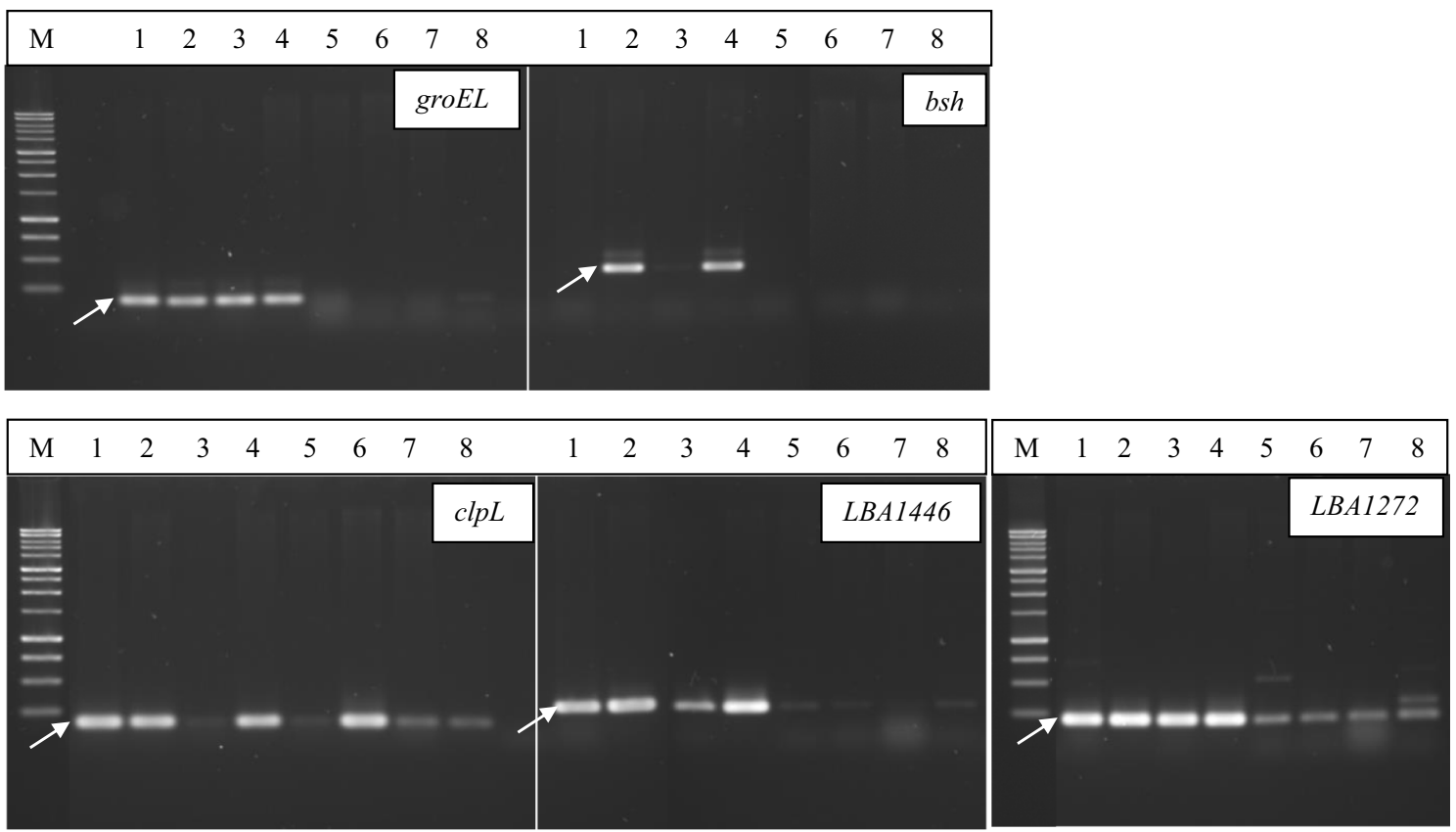

Fig. 1 Evidence of the presence in the genomic DNA of specific genes involved in the stress resistance ( $g r o E L, b s h, c l p L$, LBA1446, and LBA1272). 1, Lb. fermentum BR8; 2, Lb. plantarum BR9; 3, Lb. delbrueckii BR10; 4, Lb. plantarum CR1; 5, Lb. nagelli CR2; 6, Lb.

satsumensis CR3; 7, Lb. ghanensis CR5; 8, Lb. harbinensis CR12; M, $1 \mathrm{~kb}$ DNA ladder. Arrows indicate the position of the specific amplicon for each gene 
Table 4 Survival of the tested strains after $3 \mathrm{~h}$ of incubation at $\mathrm{pH} 2.5$ or in the presence of bile salts or GIT enzymes

\begin{tabular}{llllllll}
\hline Strain & \multicolumn{7}{l}{ Percentage of viable cells ${ }^{\mathrm{a}}(\%)$} \\
\cline { 2 - 7 } & $\mathrm{pH} 2.5$ & $0.2 \% \mathrm{BS}$ & $0.4 \% \mathrm{BS}$ & $0.8 \% \mathrm{BS}$ & $2 \% \mathrm{BS}$ & $0.3 \%$ pepsin $(\mathrm{pH} 2.5)$ & $0.1 \%$ pancreatin $(\mathrm{pH} 7.0)$ \\
\hline BR9 & $91 \pm 3$ & $\mathrm{nt}$ & $\mathrm{nt}$ & $63 \pm 3$ & $61 \pm 1$ & $90 \pm 1$ & $98 \pm 1$ \\
CR1 & $94 \pm 3$ & $\mathrm{nt}$ & $\mathrm{nt}$ & $66 \pm 5$ & $65 \pm 3$ & $95 \pm 2$ & $99 \pm 0$ \\
CR3 & $93 \pm 2$ & $\mathrm{nt}$ & $\mathrm{nt}$ & $52 \pm 6$ & $49 \pm 6$ & $85 \pm 1$ & $89 \pm 1$ \\
CR5 & $71 \pm 5$ & $78 \pm 3$ & $39 \pm 2$ & 0 & 0 & $70 \pm 5$ & $96 \pm 0$ \\
CR12 & $39 \pm 3$ & $\mathrm{nt}$ & $\mathrm{nt}$ & $49 \pm 3$ & $45 \pm 5$ & $40 \pm 6$ & $96 \pm 1$ \\
\hline
\end{tabular}

${ }^{a}$ results are given as the mean value of three values \pm standard deviation

$n t$, not tested

vegetable-based products (Kudo et al. 2012; Adimpong et al. 2013). The carbon source used in the isolation media might play an important role for the recovery of this species from a fermented product. In our study, L. delbrueckii was only isolated from MRSf, although the subsequent growth was possible on MRSg.

The LAB composition of the water kefir samples was more diverse. Four Lactobacillus species have been isolated from the beverage and two from the grains, but only L. plantarum was common for the two types of samples. Along with L. plantarum, in the grain we could find L. harbinensis, while in the home-made beverage L. nagelli, L. satsumensis, and L. ghanensis were present. Except L. ghanensis, all found lactobacilli have been previously detected in the water (sugary) kefir grains (Fiorda et al. 2017). On the other hand, L. ghanensis is common for cocoa fermentation (Nielsen et al. 2007), but it was also found in a muscovado-based kefir in the Philippines (Elegado et al. 2016). It is important to note that from MRSg we could only isolate L. plantarum and L. nagelli, while the other lactobacilli were only isolated from MRSf. This proves that the carbon source available for fermentation can influence species' diversity and frequency (Fiorda et al. 2017). Moreover, the use of various substrates (fruit) for the manufacture of water kefir may be responsible for the differences observed between the grain and beverage microbiota.

Most of the lactobacilli isolated from water kefir and braga showed antibacterial activity against several (spoilage or pathogenic) Gram-positive and Gram-negative bacteria, indicating their potential probiotic effect, but also their ability to inhibit the growth of undesirable bacteria and, consequently, their essential role in the preservation of such fermented foods (Tamang et al. 2009). The inhibitory activity was observed only when viable LAB cultures were tested. It was not detected in the CFCS or in the ammonium sulphate-precipitated CFCS. We can assume that the inhibitory activity was due to the production of organic acids, especially lactic acid, which decreases the $\mathrm{pH}$ of the surrounding medium, making it unsuitable for the growth of many other bacteria, including pathogens (Khalil et al. 2018). However L. harbinensis, producing one of the lowest amount of lactic acid, had the highest activity against most of the indicator strains. It is possible, therefore, that a combination with other organic acids, or with other compounds, contributes to the inhibitory activity. A synergistical activity of lactic acid and acetic acid has been previously reported against $E$. coli and $S$. enteritidis (Piard and Desmazeaud 1991). On the other hand, the lack of activity in the CFCS shows that the presence of the producing cells is important in order to exert the antibacterial activity.

Probiotic properties are widely spread among LAB, so the same properties can be expected with high probability in an environment with a high LAB diversity, such as the water kefir (Waldherr et al. 2010). The ability to inhibit the growth of pathogenic bacteria is an essential feature of a probiotic product. Besides that, a probiotic bacterial strain must survive the passage through the GIT, meaning a low $\mathrm{pH}$ and the presence of certain enzymes and bile salts, and must reach the target site in an adequate number to elicit an effect (Mills et al. 2011). Most of the newly isolated strains, exhibiting antibacterial activity, showed a good resistance to $\mathrm{pH} 2.5$. However, no relationship could be found between the $\mathrm{pH}$ survival capacity and the presence/absence of LBA 1272, groEL, and $c l p L$ genes that have been described to be involved in the survival at low $\mathrm{pH}$ (Turpin et al. 2011). Moreover, a good resistance to bile salts was observed for most strains. Except L. ghanensis CR5 and L. harbinensis CR12, they kept a viability of over $50 \%$ after exposure for $3 \mathrm{~h}$ to $0.8 \%$ bile salts. Among the genes screened for the bile salt resistance, the presence of $b s h$ genes seems to result in a higher survival rate of the harbouring strains in the presence of bile salts up to $2 \%$ $(w / v)$, comparing with the strains lacking these genes. The two L. plantarum strains were the only strains harbouring $b s h$ genes; they have shown a percentage of viable cells of over $60 \%$ in the presence of $2 \%$ bile salts, comparing with less than $50 \%$ for the other strains. Moreover, these two strains were the only ones able to survive, with very good viability rate, under the conditions simulating the passage through the GIT. The role of $b s h$ genes in the bile salts survival has been frequently discussed and it was shown that expression of $b s h$ genes increases after exposure to bile (Duary et al. 2012), and that strains lacking these genes are sensitive to bile salts (Turpin 
Table 5 Survival of the tested strains under conditions simulating the passage through the GIT

\begin{tabular}{llll}
\hline Strain & \multicolumn{2}{l}{ Percentage of viable cells ${ }^{\mathrm{a}}(\%)$} \\
\cline { 2 - 4 } & $\mathrm{pH} \mathrm{2.5}$ & $\begin{array}{l}0.3 \% \text { pepsin } \\
\text { 1 } \mathrm{h}\end{array}$ & $\begin{array}{l}0.1 \% \text { pancreatin }+2 \% \text { BS } \\
3 \mathrm{~h}\end{array}$ \\
\hline BR9 & $98 \pm 1$ & $94 \pm 0$ & $77 \pm 6$ \\
CR1 & $100 \pm 0$ & $96 \pm 1$ & $79 \pm 5$ \\
CR3 & $90 \pm 10$ & $90 \pm 10$ & 0 \\
CR5 & $93 \pm 3$ & $83 \pm 5$ & $55 \pm 5^{\mathrm{b}}$ \\
CR12 & $49 \pm 1$ & $47 \pm 1$ & 0
\end{tabular}

${ }^{a}$ results are given as the mean value of three values \pm standard deviation

${ }^{\mathrm{b}}$ the BS concentration in this case was $0.2 \%$, since this strain does not survive at higher BS concentrations

et al. 2011). In our study, L. satsumensis CR3 and L. harbinensis CR12, lacking bsh genes, still showed a good survival in the presence of $0.8 \%$ and even $2 \%$ of bile salts. In these two strains we could find, however, LBA 1446 genes. On the contrary, L. ghanensis CR5, lacking both $b s h$ and LBA 1446 genes, was much more sensitive, proving that LBA 1446 genes might have a contribution to the bile salts resistance. On the other hand, some of the genes thought to be involved in the $\mathrm{pH}$ or bile salt resistance, namely LBA 1272 and $\operatorname{clpL}$, were present in all strains. This could be due to the existence of a conserved domain in the corresponding proteins encoded by these genes, from several Lactobacillus species (Turpin et al. 2011). We can assume, therefore, that resistance to low $\mathrm{pH}$ and bile salts is the result of a combination of mechanisms and genes and it is variable among species and even among strains.

\section{Conclusion}

To our knowledge, this is the first report on the identification of LAB isolated from braga, a Romanian fermented beverage, closely related to boza. The presence of $L$. ghanensis in water kefir is also reported for the first time in Europe. Three Lactobacillus species were isolated from braga, and five Lactobacillus species were obtained from a home-made water kefir and the corresponding grains. Most of the tested strains were able to inhibit several Gram-positive and Gram-negative bacteria. Based on their antimicrobial activity and their good resistance to low $\mathrm{pH}$ and high concentrations of bile salts, and also based on their good survival under conditions simulating the passage through the GIT, L. plantarum BR9, isolated from braga, and $L$. plantarum CR1, isolated from water kefir, seem to be promising candidates for designing new probiotic products. In contrast to the milk kefir, one of the main benefits of water kefir or cereal-based beverages is the possibility to be consumed by vegetarians and lactose-intolerant consumers (Fiorda et al. 2016).
Acknowledgements The authors thank Dr. Gina Cogalniceanu for providing the water kefir samples, and Dr. Diana Pelinescu and Prof. CalinaPetruta Cornea for providing the indicator strains used for the antibacterial activity assay.

Funding information This work was financially supported by a grant of the Romanian National Authority for Scientific Research, CNDIUEFISCDI, project number 105/2012 (PLANTLAB), and by the project RO1567-IBB05/2018 from the Institute of Biology Bucharest of Romanian Academy.

\section{Compliance with ethical standards}

Conflict of interest The authors declare that they have no conflict of interest.

Research involving human participants and/or animals N/A

Informed consent N/A

Open Access This article is licensed under a Creative Commons Attribution 4.0 International License, which permits use, sharing, adaptation, distribution and reproduction in any medium or format, as long as you give appropriate credit to the original author(s) and the source, provide a link to the Creative Commons licence, and indicate if changes were made. The images or other third party material in this article are included in the article's Creative Commons licence, unless indicated otherwise in a credit line to the material. If material is not included in the article's Creative Commons licence and your intended use is not permitted by statutory regulation or exceeds the permitted use, you will need to obtain permission directly from the copyright holder. To view a copy of this licence, visit http://creativecommons.org/licenses/by/4.0/.

\section{References}

Adimpong DB, Nielsen DS, Sørensen KI et al (2013) Lactobacillus delbrueckii subsp. jakobsenii subsp. nov., isolated from dolo wort, an alcoholic fermented beverage in Burkina Faso. Int J Syst Evol Microbiol 63:3720-3726. https://doi.org/10.1099/ijs.0.048769-0

Afilipoie I-A, Gontariu I (2015) Rediscovery of refreshing drink-braga and contributions to its advanced characterisation. Ann Food Sci Technol 16:10

Beijerinck MW (1889) Sur le kefir. Arch Neerl Sci Exactes Nat 23:248 258

Blandino A, Al-Aseeri ME, Pandiella SS et al (2003) Cereal-based fermented foods and beverages. Food Res Int 36:527-543. https:// doi.org/10.1016/S0963-9969(03)00009-7

Duary RK, Batish VK, Grover S (2012) Relative gene expression of bile salt hydrolase and surface proteins in two putative indigenous Lactobacillus plantarum strains under in vitro gut conditions. Mol Biol Rep 39:2541-2552. https://doi.org/10.1007/s11033-0111006-9

Elegado FB, Colegio SMT, Lim VMT et al (2016) Ethnic fermented foods of the Philippines with reference to lactic acid bacteria and yeasts. In: Ethnic fermented foods and alcoholic beverages of Asia. Springer, New Delhi, pp 323-340

Fiorda FA, de Melo Pereira GV, Thomaz-Soccol V et al (2016) Development of kefir-based probiotic beverages with DNA protection and antioxidant activities using soybean hydrolyzed extract, colostrum and honey. LWT Food Sci Technol 68:690-697. https:// doi.org/10.1016/j.lwt.2016.01.003 
Fiorda FA, de Melo Pereira GV, Thomaz-Soccol V et al (2017) Microbiological, biochemical, and functional aspects of sugary kefir fermentation-a review. Food Microbiol 66:86-95. https://doi.org/10. 1016/j.fm.2017.04.004

Golowczyc MA, Silva J, Teixeira P et al (2011) Cellular injuries of spraydried Lactobacillus spp. isolated from kefir and their impact on probiotic properties. Int J Food Microbiol 144:556-560. https:// doi.org/10.1016/j.ijfoodmicro.2010.11.005

Grosu-Tudor S-S, Stancu M-M, Pelinescu D, Zamfir M (2014) Characterization of some bacteriocins produced by lactic acid bacteria isolated from fermented foods. World J Microbiol Biotechnol 30:2459-2469. https://doi.org/10.1007/s11274-014-1671-7

Gulitz A, Stadie J, Wenning M et al (2011) The microbial diversity of water kefir. Int J Food Microbiol 151:284-288. https://doi.org/10. 1016/j.ijfoodmicro.2011.09.016

Gulitz A, Stadie J, Ehrmann MA et al (2013) Comparative phylobiomic analysis of the bacterial community of water kefir by $16 \mathrm{~S}$ rRNA gene amplicon sequencing and ARDRA analysis. J Appl Microbiol 114:1082-1091. https://doi.org/10.1111/jam.12124

Khalil ES, Manap MY, Mustafa S et al (2018) Probiotic characteristics of exopolysaccharides-producing Lactobacillus isolated from some traditional Malaysian fermented foods. CyTA - J Food 16:287298. https://doi.org/10.1080/19476337.2017.1401007

Kudo Y, Oki K, Watanabe K (2012) Lactobacillus delbrueckii subsp. sunkii subsp. nov., isolated from sunki, a traditional Japanese pickle. Int J Syst Evol Microbiol 62:2643-2649. https://doi.org/10.1099/ijs. 0.037051-0

Laureys D, De Vuyst L (2014) Microbial species diversity, community dynamics, and metabolite kinetics of water kefir fermentation. Appl Environ Microbiol 80:2564-2572. https://doi.org/10.1128/AEM. 03978-13

Man JCD, Rogosa M, Sharpe ME (1960) A medium for the cultivation of lactobacilli. J Appl Bacteriol 23:130-135. https://doi.org/10.1111/j. 1365-2672.1960.tb00188.x

Markoviak P, Śliżewska K (2017) Effects of probiotics, prebiotics, and synbiotics on human health. Nutrients 9(9):1021-1051. https://doi. org/10.3390/nu9091021

Marsh AJ, Hill C, Ross RP, Cotter PD (2014) Fermented beverages with health-promoting potential: past and future perspectives. Trends Food Sci Technol 38:113-124. https://doi.org/10.1016/j.tifs. 2014.05.002

Mayr-Harting A, Hedges AJ, Berkeley RCW (1972) Chapter VII methods for studying bacteriocins. In: Ribbons DW (ed) Norris JR. Academic Press, Methods in Microbiology, pp 315-422

Mills S, Stanton C, Fitzgerald GF, Ross RP (2011) Enhancing the stress responses of probiotics for a lifestyle from gut to product and back again. Microb Cell Factories 10:S19. https://doi.org/10.1186/14752859-10-S1-S19

Mitrea L, Calinoiu LF, Precup G, Bindea M, Rusu B, Trif M, Ferenczi LJ, Stefanescu BE, Vodnar DC (2017) Inhibitory potential of Lactobacillus plantarum on Escherichia coli. Bull Univ Agric Sci Vet Med Cluj-Napoca-Food Sci Technol 74(2):99-101

Muneer Alsayadi MA, Jawfi YA, Belarbi M, Sabri FZ (2018) Antioxidant potency of water kefir. J Microbiol Biotechnol Food Sci 7:2444-2447
Nielsen DS, Schillinger U, Franz CMAP et al (2007) Lactobacillus ghanensis sp. nov., a motile lactic acid bacterium isolated from Ghanaian cocoa fermentations. Int J Syst Evol Microbiol 57:14681472. https://doi.org/10.1099/ijs.0.64811-0

Piard JC, Desmazeaud M (1991) Inhibiting factors produced by lactic acid bacteria. 1. Oxygen metabolites and catabolism end-products. Lait 71:525-541. https://doi.org/10.1051/lait:1991541

Prado MR, Blandón LM, Vandenberghe LPS, et al (2015) Milk kefir: composition, microbial cultures, biological activities, and related products: Front Microbiol 6. https://doi.org/10.3389/fmicb.2015. 01177

Quigley EMM (2013) Gut bacteria in health and disease. Gastroenterol Hepatol (N Y) 9:560-569

Rodrigues KL, Araújo TH, Schneedorf JM et al (2016) A novel beer fermented by kefir enhances anti-inflammatory and antiulcerogenic activities found isolated in its constituents. J Funct Foods 21:58-69. https://doi.org/10.1016/j.jff.2015.11.035

Sõukand R, Pieroni A, Biró M et al (2015) An ethnobotanical perspective on traditional fermented plant foods and beverages in Eastern Europe. J Ethnopharmacol 170:284-296. https://doi.org/10.1016/j. jep.2015.05.018

Stefanut C, Mitrea L, Ognean L (2015) Effects of probiotics, prebiotics and synbiotics on some hematological and microbiological parameters in laboratory mice. Bull UASVM Vet Med 72(2):301-305. https://doi.org/10.15835/buasvmen-vm:11435

Tamang JP, Tamang B, Schillinger U et al (2009) Functional properties of lactic acid bacteria isolated from ethnic fermented vegetables of the Himalayas. Int J Food Microbiol 135:28-33. https://doi.org/10. 1016/j.ijfoodmicro.2009.07.016

Todorov SD, Holzapfel WH (2015) 6-traditional cereal fermented foods as sources of functional microorganisms. In: Advances in Fermented Foods and Beverages. Woodhead Publishing, pp 123-153

Turpin W, Humblot C, Guyot J-P (2011) Genetic screening of functional properties of lactic acid bacteria in a fermented pearl millet slurry and in the metagenome of fermented starchy foods. Appl Environ Microbiol 77:8722-8734. https://doi.org/10.1128/AEM.05988-11

Versalovic J, Schneider GM, Bruijn F, Lupski JR (1994) Genomic fingerprint of bacteria using repetitive sequence-based polymerase chain reaction. Methods Mol Cell Biol 5:25-40

von Mollendorff JW, Vaz-Velho M, Todorov SD (2016) Boza, a traditional cereal-based fermented beverage: a rich source of probiotics and bacteriocin-producing lactic acid bacteria. In: Functional properties of traditional foods. Springer, Boston, pp 157-188

Waldherr FW, Doll VM, Meissner D, Vogel RF (2010) Identification and characterization of a glucan-producing enzyme from Lactobacillus hilgardii TMW 1.828 involved in granule formation of water kefir. Food Microbiol 27:672-678. https://doi.org/10. 1016/j.fm.2010.03.013

Zanirati DF, Abatemarco M, Sandes SH d C et al (2015) Selection of lactic acid bacteria from Brazilian kefir grains for potential use as starter or probiotic cultures. Anaerobe 32:70-76. https://doi.org/10. 1016/j.anaerobe.2014.12.007

Publisher's note Springer Nature remains neutral with regard to jurisdictional claims in published maps and institutional affiliations. 